Article

\title{
Utilization of Silicon Carbide Sludge as Metakaolin-Based Geopolymer Materials
}

\author{
Kae-Long Lin ${ }^{1}\left(\mathbb{D}\right.$, Kang-Wei Lo $\left.{ }^{2,3}, * \mathbb{(}\right)$, Ta-Wui Cheng ${ }^{3}\left(\mathbb{D}\right.$, Wei-Ting Lin ${ }^{4}\left(\mathbb{D}\right.$ and Ya-Wen Lin $^{3}$ \\ 1 Department of Environmental Engineering, National Ilan University, Ilan City 260, Taiwan; kllin@niu.edu.tw \\ 2 Graduate Institute of Engineering Technology, National Taipei University of Technology, Taipei City 106, Taiwan \\ 3 Institute of Mineral Resources Engineering, National Taipei University of Technology, Taipei City 106, Taiwan; \\ twcheng@ntut.edu.tw (T.-W.C.); urine1001@gmail.com (Y.-W.L.) \\ 4 Department of Civil Engineering, National Ilan University, Ilan 260, Taiwan; wtlin@niu.edu.tw \\ * Correspondence: dark83054689@gmail.com; Tel.: +886-3935-7579
}

Received: 10 August 2020; Accepted: 3 September 2020; Published: 7 September 2020

check for updates

\begin{abstract}
The recycling of $\mathrm{SiC}$ sludge material is crucial for resource reutilization and environmental protection. In the current study, the effect of the mass ratio between the $\mathrm{Na}_{2} \mathrm{SiO}_{3}$ and sodium hydroxide $(\mathrm{NaOH})$ solutions (NS/SS ratio) and the effect of $\mathrm{SiC}$ sludge on metakaolin geopolymers was comprehensively investigated to determine the underlying performance of the geopolymerization system. During thermal evolution, the second exothermic peak of 1.6NS10SCS (NS/SS ratio: 1.6, $10 \% \mathrm{SiC}$ sludge) showed a heat evolution value of $990.6 \mathrm{~W} / \mathrm{g}$, which was the highest among other geopolymers. Additionally, the 1.6NS10SCS sample after 28 days of curing showed the highest flexural strength (6.42 MPa), compared to that of the others, and the DTA/TG (differential thermal analysis/thermogravimetry) results showed that the weight loss percentage increased to $14.62 \%$ from 400 to $750{ }^{\circ} \mathrm{C}$. For the ${ }^{29} \mathrm{Si}$ nuclear magnetic resonance deconvolution, 1.6NS10SCS exhibited high fractions of $\mathrm{Q}^{4}(3 \mathrm{Al})(33.63 \%), \mathrm{Q}^{4}(2 \mathrm{Al})(23.92 \%)$, and $\mathrm{Q}^{4}(1 \mathrm{Al})(9.70 \%)$. Thus, the geopolymer with the optimal SiC-sludge replacement level and NS/SS ratio contained more macropores and geopolymer gels, which benefit structural development. The experimental results indicated that SiC-sludge can potentially serve as a partial replacement for metakaolin and exhibited favorable mechanic characteristics.
\end{abstract}

Keywords: utilization; $\mathrm{SiC}$ sludge; alkaline activator solutions; synergistic effect; geopolymer reaction

\section{Introduction}

The solar cells generated electricity will become the primary global energy source, because the solar power was safe, efficient, nonpolluting and reliable [1]. Recycling silicon is of great importance, because the demand for silicon for solar cells is increasing globally, while concern about the limited silicon supply is emerging [2]. Generally, solar cells use multicrystalline wafers made of silicon [1]. Crystalline silicon cells have laboratory energy conversion efficiencies over $25 \%$ for single-crystal cells and over $20 \%$ for multicrystalline cells. In 2008, more than $100 \mathrm{GW}$ silicon solar panels were produced based on an energy-intensive Siemens process [3], which cost approximately 400,000 tons of silicon. There were various types of solar cells, whereby the C-Si solar cell dominates $80 \%$ of the market globally [1]. Industry mainly uses silicon carbide ( $\mathrm{SiC}$ ) for wafer slicing [4], and a substantial amount of $\mathrm{SiC}$ sludge is formed when a silicon ingot is cut into wafers, with a kerf loss of over $50 \%$ [5]. The kerf-loss silicon waste is greater than 200,000 tons per year, and this sludge contributes to environmental pollution. Therefore, the recycling of $\mathrm{SiC}$ sludge material is crucial for resource reutilization and environmental protection. In addition, the primary composition of $\mathrm{SiC}$ sludge is $\mathrm{SiO}_{2}$ 
and $\mathrm{Al}_{2} \mathrm{O}_{3}$. Therefore, $\mathrm{SiC}$ sludge can be used as a raw material in producing silicon carbide sludge metakaolin-based (SCSMB) geopolymers.

Inorganic polymer (geopolymer) is a cementation material that can be used as an alternative to ordinary Portland cement. Geopolymers are mostly formed by mixing silicate aluminum sources (industrial waste such as slag and fly ash) with alkaline silicate solutions or an alkaline metal [6]. The polymerization process produced a three-dimensional (3D) compound comprising of $\left[\mathrm{AlO}_{4}\right]$ and $\left[\mathrm{SiO}_{4}\right]$ tetrahedrons $[7,8]$. Geopolymerization begins with the generation of -Si-O-Al-O-Si- or -Si-O-Al- monomers (oligomers) in the solution. These monomers join to form a geopolymer. As a structural material, a geopolymer is a potential replacement material for ordinary Portland cement (OPC). The most common alkaline activator solution (AAS) is a combination of $\mathrm{Na}_{2} \mathrm{SiO}_{3}$ and $\mathrm{NaOH}$. AAS plays a crucial role in the polymerization process, which in turn has a strong dependence on the $\mathrm{Si} / \mathrm{Al}$ ratio, $\mathrm{M}_{2} \mathrm{O}-\mathrm{H}_{2} \mathrm{O}$ ratio (where $\mathrm{M}=\mathrm{Na}$ and/or $\mathrm{K}$ ), hydroxide concentration, and alkali cation used [9-12].

Recently, there have been many studies on SiC sludge applied in the field of geopolymer materials. For example, Medri et al. [13] reported that silicon carbide ( $\mathrm{SiC}$ ) foams were developed using a low-temperature process, such as chemical consolidation, that is suitable for replacing the sintering step. The amorphous silica layer covering the surface of $\mathrm{SiC}$ particles participates in geopolymerization so that nanoprecipitates easily form on the SiC surface [13]. Rahman et al. [14] reported that silicon carbide whiskers were introduced into sodium-based geopolymers in order to evaluate the response of silicon carbide whiskers to the interfacial bonding and strength of sodium-based geopolymers along with rice husk ashes. Results show that the simultaneous additions of rice husk ashes and silicon carbide whiskers resulted in flexural strength improvement by $\sim 27 \%$ and $\sim 97 \%$, respectively. The increase in flexural strength due to simultaneous inclusion of silica and silicon carbide whiskers suggests that silica particles are compatible with the metakaolin-based geopolymers, which is effective in consolidation [14]. Medri et al. [14] reported that refractory paints based on silicon carbide ( $\mathrm{SiC})$ were developed using inorganic alkali-aluminosilicate binders. R-SiC coatings applied by brushing on a $\mathrm{Si}_{3} \mathrm{~N}_{4}$-TiN substrate cannot act as barriers against oxygen penetration due to the presence of large pores [15]. Bai et al. [16] reported that high-strength open-celled SiC/geopolymer foam composites (SFCs) were fabricated by a combined saponification/peroxide route. The optimal sample possessed a total porosity of up to $\sim 84 \mathrm{vol} \%$, an open porosity of $\sim 83 \mathrm{vol} \%$, a thermal conductivity of $0.15 \mathrm{~W} / \mathrm{mK}$, and a compression strength of $\sim 1.1 \mathrm{MPa}$ [16]. Jia et al. [17] reported that bulk and porous AlN/SiC-based ceramics were prepared in situ from graphite/geopolymer composites based on a carbon thermal reduction reaction under high temperatures. Moreover, both h-AlN and $\mathrm{SiC}$ ceramics derived by this technique show porous features, with porosities of $61 \%$ and $68 \%$ and considerable compressive strength values of $0.76 \mathrm{MPa}$ and $0.63 \mathrm{MPa}$, respectively [17]. Although, previous investigations have studied SiC sludge in the field of geopolymer materials, such as silicon carbide (SiC) foams [13], SiCf-reinforced geopolymers [14], refractory paints [15], high-strength open-celled SiC/geopolymer foam composites (SFCs) [16], and porous AlN/SiC-based ceramics [17].

Most of the previous investigations were based on studies on $\mathrm{SiC}$ sludge applied in the field of geopolymer materials, which led to knowledge; few reports are available regarding the effect of alkaline-activator solution on the geopolymerization of $\mathrm{SiC}$ sludge-based geopolymers. In this study, a new way to the effect of the mass ratio between the $\mathrm{Na}_{2} \mathrm{SiO}_{3}$ and sodium hydroxide $(\mathrm{NaOH})$ solutions (NS/SS ratio) and the effect of SiC sludge on metakaolin geopolymers was comprehensively investigated to determine the underlying performance of the geopolymerization system. The flexural strengths of the geopolymers were examined in a laboratory, and their microstructures were characterized using an isothermal conduction calorimeter, differential thermal analysis (DTA/TG), and nuclear magnetic resonance (NMR). 


\section{Materials and Methods}

The silicate-aluminum sources were metakaolin (MK) and SiC sludge. The SiC sludge was gained from a plant that makes LED substrates (Taiwan). The major chemical composition of the SiC sludge was $75.4 \mathrm{wt} \% \mathrm{SiO}_{2}, 23 \mathrm{wt} \% \mathrm{SiC}$, and $0.8 \mathrm{wt} \% \mathrm{Al}_{2} \mathrm{O}_{3}$; the major chemical composition of the $\mathrm{MK}$ was $51.8 \mathrm{wt} \% \mathrm{SiO}_{2}$ and $43 \mathrm{wt} \% \mathrm{Al}_{2} \mathrm{O}_{3}$, as shown in Table 1 . Sodium hydroxide $(\mathrm{NaOH}, 10 \mathrm{M})$ and distilled water were mixed with a commercial sodium silicate solution $\left(\mathrm{Na}_{2} \mathrm{SiO}_{3}\right), \mathrm{Ms}\left(\mathrm{SiO}_{2} \mathrm{~mole} / \mathrm{Na}_{2} \mathrm{O}\right.$ mole $)=3.1\left(\mathrm{SiO}_{2}=28.1 \%, \mathrm{Na}_{2} \mathrm{O}=9.09 \%, \mathrm{H}_{2} \mathrm{O}=62.8 \%\right)$. The mass ratio between $\mathrm{Na}_{2} \mathrm{SiO}_{3}$ and sodium hydroxide $(\mathrm{NaOH})$ solutions (NS/SS ratio) was in the range of 0.8 to $2.0(0.8,1.2,1.6$, and 2.0) and analysis of the effect of an alkaline-activator solution on a geopolymer reaction. Calculate the amount of NS/SS ratio as follows.

$$
\begin{gathered}
\mathrm{NS} / \mathrm{SS} \text { ratio }=\mathrm{SiO}_{2} \text { mole }\left(\text { Sodium silicate solution) } /\left[\mathrm{Na}_{2} \mathrm{O} \text { mole }(\text { Sodium silicate }\right.\right. \\
\text { solution } \left.)+\mathrm{Na}_{2} \mathrm{O} \text { mole }(10 \mathrm{M} \mathrm{NaOH})\right]
\end{gathered}
$$

\begin{tabular}{|c|c|c|}
\hline Composition & SiC Sludge & MK \\
\hline $\mathrm{SiO}_{2}(\mathrm{wt} \%)$ & 75.40 & 51.80 \\
\hline $\mathrm{Al}_{2} \mathrm{O}_{3}($ wt $\%)$ & 0.80 & 43.00 \\
\hline $\mathrm{Fe}_{2} \mathrm{O}_{3}($ wt $\%)$ & 0.58 & 1.30 \\
\hline $\mathrm{CaO}(w \mathrm{t} \%)$ & 0.09 & 0.25 \\
\hline $\mathrm{MgO}($ wt \%) & N.D. ${ }^{1}$ & N.D. ${ }^{1}$ \\
\hline $\mathrm{SO}_{3}(\mathrm{wt} \%)$ & 0.06 & N.D. ${ }^{1}$ \\
\hline $\mathrm{Na}_{2} \mathrm{O}($ wt $\%)$ & N.D. ${ }^{1}$ & 0.04 \\
\hline $\mathrm{K}_{2} \mathrm{O}(\mathrm{wt} \%)$ & 0.01 & 0.32 \\
\hline $\mathrm{SiC}($ wt $\%)$ & 23.00 & N.D. ${ }^{1}$ \\
\hline
\end{tabular}

Table 1. The major chemical composition of materials.

Then, MK and 0-40 wt \% SiC sludge were added into an alkali activator, and analysis of the effect of a $\mathrm{Si} / \mathrm{Al}$ mole ratios on a geopolymer reaction. The ratios of material in the mixture of geopolymers are listed in Table 2. Calculate the amount of $\mathrm{Si} / \mathrm{Al}$ mole ratios as follows. First, the MK, $\mathrm{SiC}$ sludge, and alkaline solution were stirred for $60 \mathrm{~min}$, and deionized water $(3.8 \mathrm{~L})$ was subsequently added to the blend to generate a suspension by stirring for $30 \mathrm{~s}$. After filtration, the dissolved $\mathrm{Si}$ and $\mathrm{Al}$ concentrations were measured by atomic absorption spectroscopy (AAS). SiC-sludge metakaolin-based geopolymer samples were synthesized by mixing powder and alkaline activator solution for $5 \mathrm{~min}$, and the paste was poured into a plastic mold for the analysis of microstructure characteristics and mechanical properties. The flexural strength tests were performed after 1, 7, 14, 28, and 56 days using a Hung Ta HT-2402 testing machine (Hung Ta Instruments, Taichung City, Taiwan) with a three-point bending test method, according to ASTM C348. The average strength value of the three specimens is presented, and the coefficient of variation of these results is less than $10 \%$. The mechanical properties of the three specimens were evaluated and expressed. Finally, the samples were analyzed at appropriate curing times by DTA/TG and ${ }^{29}$ Si MAS NMR analyses. The heat evolution in the geopolymerization reactions, such as dissolution, polymerization, and condensation, were characterized by an isothermal conduction calorimeter (Calmetrix I-CAL 2000 HPC, Boston, MA, USA) conducted at a constant temperature of $30 \pm 0.02{ }^{\circ} \mathrm{C}$ for $168 \mathrm{~h}$, according to ASTM C1702. The DTA/TG studies were conducted, in which the heating range was from $50^{\circ} \mathrm{C}$ to $1000^{\circ} \mathrm{C}$ by an STA6000 thermal analyzer. High-resolution 29Si MAS/NMR spectra were recorded at $39.72 \mathrm{MHz}$ on an MSL Bruker MAS/NMR-200 solid-state high-resolution spectrometer using rapid (approximately $3 \mathrm{kHz}$ ) sample spinning at the magic angle to the external magnetic field. Analysis method based on reference [18], the coordination of $\mathrm{Q}^{4}(\mathrm{mAl})$ species (4Al, 3Al, 2Al, 1Al, 0Al) in the SCSMB geopolymer was obtained by applying Seasolve PeakFit ${ }^{\mathrm{TM}}$ software, version 4 (Seasolve Software Inc., Framingham, MA, USA). 
Table 2. The ratios of material in mixture.

\begin{tabular}{|c|c|c|c|c|c|c|}
\hline Mix Designation & NS/SS & $\begin{array}{l}\text { MK } \\
(g)\end{array}$ & $\begin{array}{l}\text { SiC Sludge } \\
\text { (g) }\end{array}$ & $\begin{array}{l}\text { Sodium Silicate Solution } \\
\text { (g) }\end{array}$ & $\underset{\text { (g) }}{10 \mathrm{M} \mathrm{NaOH}}$ & Si/Al Mole Ratios \\
\hline $0.8 \mathrm{NSOSCS}$ & \multirow{5}{*}{0.8} & 500 & 0 & 240 & 260 & 1.01 \\
\hline $0.8 \mathrm{NS} 10 \mathrm{SCS}$ & & 450 & 50 & 240 & 260 & 1.36 \\
\hline $0.8 \mathrm{NS} 20 \mathrm{SCS}$ & & 400 & 100 & 240 & 260 & 1.24 \\
\hline $0.8 \mathrm{NS} 30 \mathrm{SCS}$ & & 350 & 150 & 240 & 260 & 1.74 \\
\hline $0.8 \mathrm{NS} 40 \mathrm{SCS}$ & & 300 & 200 & 240 & 260 & 2.60 \\
\hline $1.2 \mathrm{NSOSCS}$ & \multirow{5}{*}{1.2} & 500 & 0 & 315 & 185 & 0.98 \\
\hline $1.2 \mathrm{NS} 10 \mathrm{SCS}$ & & 450 & 50 & 315 & 185 & 1.34 \\
\hline $1.2 \mathrm{NS} 20 \mathrm{SCS}$ & & 400 & 100 & 315 & 185 & 1.22 \\
\hline $1.2 \mathrm{NS} 30 \mathrm{SCS}$ & & 350 & 150 & 315 & 185 & 1.87 \\
\hline $1.2 \mathrm{NS} 40 \mathrm{SCS}$ & & 300 & 200 & 315 & 185 & 2.72 \\
\hline 1.6NSOSCS & \multirow{5}{*}{1.6} & 500 & 0 & 374 & 126 & 1.16 \\
\hline $1.6 \mathrm{NS} 10 \mathrm{SCS}$ & & 450 & 50 & 374 & 126 & 1.51 \\
\hline $1.6 \mathrm{NS} 20 \mathrm{SCS}$ & & 400 & 100 & 374 & 126 & 1.43 \\
\hline 1.6NS30SCS & & 350 & 150 & 374 & 126 & 1.92 \\
\hline $1.6 \mathrm{NS} 40 \mathrm{SCS}$ & & 300 & 200 & 374 & 126 & 2.89 \\
\hline 2.0NSOSCS & \multirow{5}{*}{2.0} & 500 & 0 & 421 & 79 & 1.07 \\
\hline 2.0NS10SCS & & 450 & 50 & 421 & 79 & 1.48 \\
\hline 2.0NS20SCS & & 400 & 100 & 421 & 79 & 1.23 \\
\hline 2.0NS30SCS & & 350 & 150 & 421 & 79 & 1.78 \\
\hline 2.0NS40SCS & & 300 & 200 & 421 & 79 & 2.67 \\
\hline
\end{tabular}

\section{Results}

\subsection{Heat Evolution of Geopolymers with SiC Sludge}

Geopolymers comprise a framework containing inorganic T-O (T: Si or Al). Geopolymerization is analogous to the curing process of polymers, which includes gelation, polymerization, and solidification [9]. The heat evolution can be measured by an isothermal conduction calorimeter, which indicates the progress of the geopolymerization reaction. In all cases, the first exothermic peak, which is related to the dissolution of solid materials in the alkaline activator, is quite sharp at the beginning of the preinduction period [19]. The samples were mixed outside the device, and the heat evolution was so fast that there was not sufficient time to achieve thermal equilibrium; thus, the first peak was only partially registered. The second exothermic peak indicated continuous dissolution and polymerization, during which oligomers combined to form a geopolymer network.

Figure 1a-d illustrates the effects of the NS/SS ratio on the heat evolution during geopolymerization reactions. When the NS/SS ratio was 0.8 , the heat evolutions of $0.8 \mathrm{NS} 0 \mathrm{SCS}, 0.8 \mathrm{NS} 10 \mathrm{SCS}, 0.8 \mathrm{NS} 20 \mathrm{SCS}$, and $0.8 \mathrm{NS} 30 \mathrm{SCS}$ were $806.5,720.3,415.3$, and $445.8 \mathrm{~W} / \mathrm{g}$ heat, respectively (Figure $1 \mathrm{a}$ ). The high $\mathrm{NaOH}$ concentration prompted the dissolution of the initial solid in the alkaline activator, which caused the first exothermic peaks of 0.8NS0SCS and 0.8NS10SCS to be more intense than those of the others. In addition, the second exothermic peaks of 0.8NSOSCS and 0.8NS10SCS appeared at approximately $6.65 \mathrm{~h}$ and $9.98 \mathrm{~h}$, respectively. This indicated that a higher $\mathrm{NaOH}$ content promoted the reactivity of the geopolymerization reaction. However, the second exothermic peak of $0.8 \mathrm{NS} 40 \mathrm{SCS}$ emerged at $14.82 \mathrm{~h}$. According to $\mathrm{Hu}$ et al. [20], the geopolymer gel formed by the rapid reaction of active aluminosilicate under a high concentration of alkali hindered the subsequent dissolution of the FA (Fly ash) [20]. The results indicate that the amounts of dissolved silica and alumina from MK are limited due to precipitations of geopolymer gels around the surface of SCS particles. Therefore, the heat evolution duration of the second exothermal peak clearly increased from $6.65 \mathrm{~h}$ to $14.82 \mathrm{~h}$ as the $\mathrm{SiC}$ sludge-replacement levels increased from $0 \%$ to $40 \%$, as shown in Figure 1 a. An increase in the NS/SS ratio (1.2) was expected to improve the geopolymerization reaction, and the results of 1.2NS10SCS showed that the second exothermic peak reached $958.3 \mathrm{~W} / \mathrm{g}$. A synergistic effect between the SCS and the MK was suggested to contribute to the promotion of the geopolymerization reaction, which caused the heat evolution of 1.2NS10SCS to be higher than that of $1.2 \mathrm{NS} 0 \mathrm{SCS}(945.2 \mathrm{~W} / \mathrm{g})$. Additionally, the heat evolution duration of the second exothermal peak increased from 14.82 to $17.82 \mathrm{~h}$ as the NS/SS ratio increased from 0.8 to 1.2 (0.8NS40SCS and 1.2NS40SCS). According to Figure 1b, it can be inferred 
that, although the NS/SS ratio increased, the amounts of dissolved silica and alumina from MK were limited due to the precipitations of geopolymer gels around the surface of SCS (SiC sludge) particles.

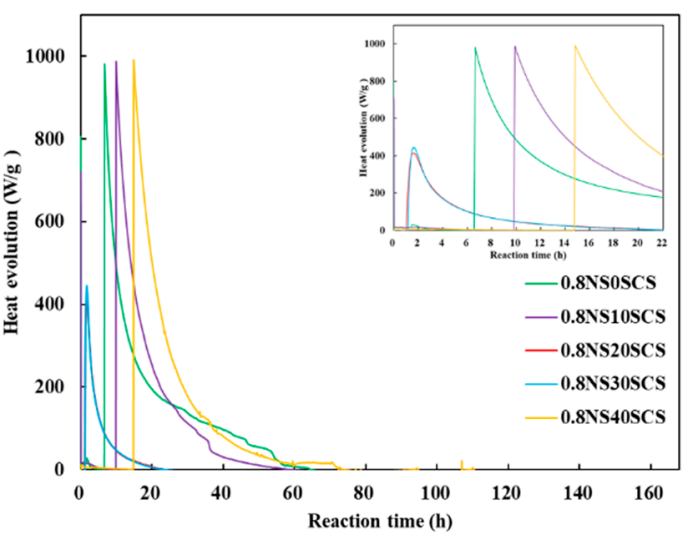

(a)

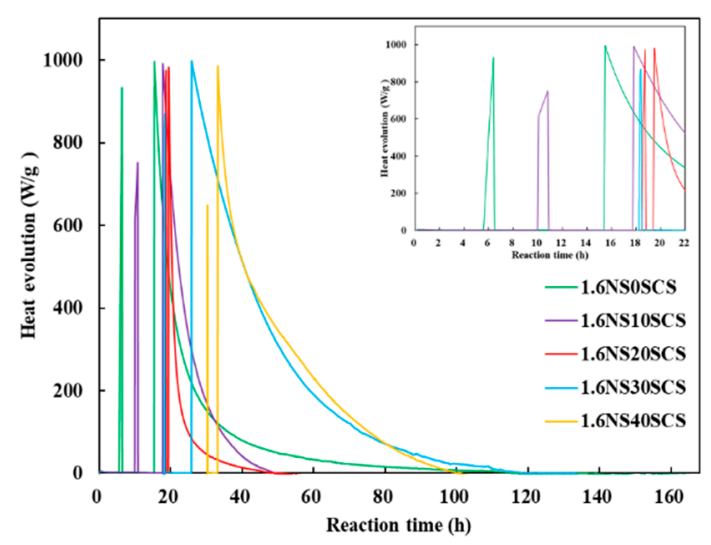

(c)

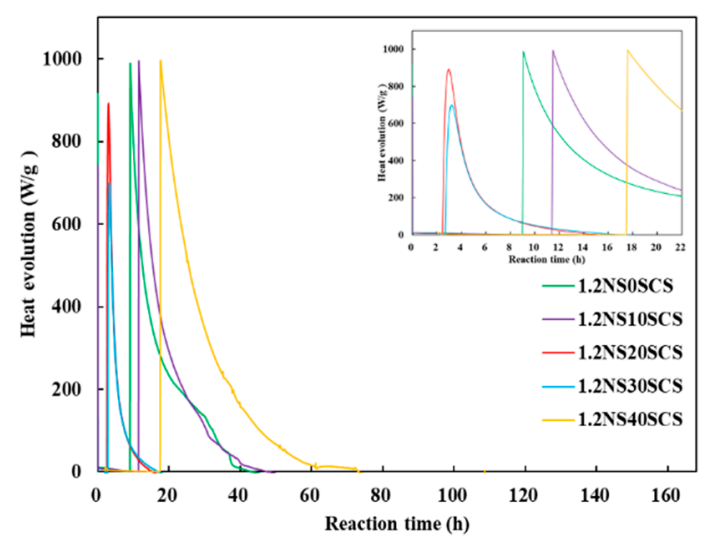

(b)

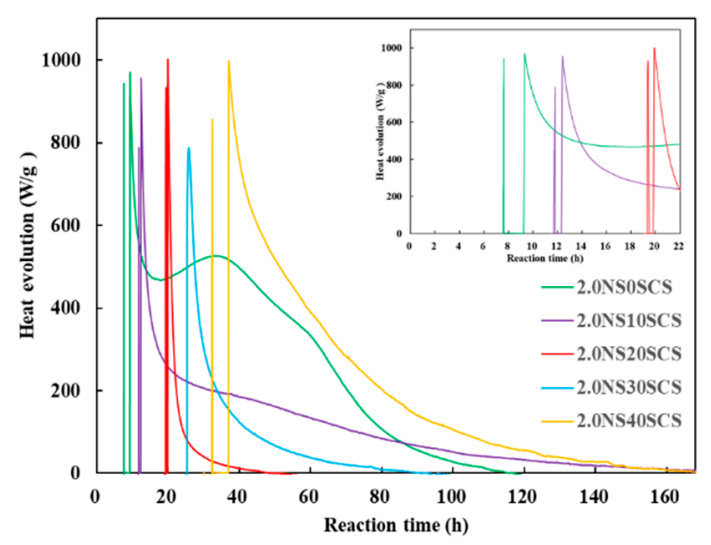

(d)

Figure 1. Effects of $\mathrm{NS} / \mathrm{SS}\left(\mathrm{Na}_{2} \mathrm{SiO}_{3} / \mathrm{NaOH}\right.$ solutions) ratios on heat evolution rate for geopolymer with $\mathrm{SiC}$ sludge: $(\mathbf{a}) \mathrm{NS} / \mathrm{SS}$ ratio $=0.8 ;(\mathbf{b}) \mathrm{NS} / \mathrm{SS}$ ratio $=1.2 ;(\mathbf{c}) \mathrm{NS} / \mathrm{SS}$ ratio $=1.6 ;(\mathbf{d}) \mathrm{NS} / \mathrm{SS}$ ratio $=2.0$.

Figure 1c-d shows the heat evolution curves of the SCSMB geopolymer sample with NS/SS values of 1.6 and 2.0, in which two exothermic peaks are classified. The heat evolution $(990.6 \mathrm{~W} / \mathrm{g})$ of the second exothermic peak of 1.6NS10SCS was higher than those of all geopolymers. This fact implies that the synergistic effect promoted the oligomers to combine and form integral geopolymer gels [20]. However, for 2.0NS10SCS, the heat evolution of the second exothermic peak decreased from $990.6 \mathrm{~W} / \mathrm{g}$ to $951.5 \mathrm{~W} / \mathrm{g}$ with an increase in the NS/SS ratio. According to Lo et al. [21], decreasing the concentration of $\mathrm{Na}_{2} \mathrm{O}$ caused the decreased of the amount of dissolved $\mathrm{Si}$ and $\mathrm{Al}$ and restrained the geopolymer synthesis reaction.

\subsection{Mechanical Properties}

The results of the flexural strength of the geopolymer with $\mathrm{SiC}$ sludge cured for 1-56 days are shown in Figure 2. The flexural strength of geopolymers varied at different replacement levels of $\mathrm{SiC}$ sludge and was positively correlated with the replacement levels. On the first day of the curing process, the flexural strengths of $0.8 \mathrm{NS} 0 \mathrm{SCS}, 0.8 \mathrm{NS} 10 \mathrm{SCS}, 0.8 \mathrm{NS} 20 \mathrm{SCS}, 0.8 \mathrm{NS} 30 \mathrm{SCS}$, and 0.8NS40SCS were $4.12,3.97,3.89,3.56$, and $3.57 \mathrm{MPa}$, respectively (Figure 2a). The amounts of dissolved silica and alumina from MK are limited due to geopolymer gel precipitations around the surface of SCS particles. This reduction generated an inadequate amount of leading precursors, thus reducing the strength. Hu et al. [20] discussed that the decrease in strength at a longer curing age might be due to 
depolymerization or dissolution of aluminosilicates resulting from the low $\mathrm{SiO}_{2} / \mathrm{Al}_{2} \mathrm{O}_{3}$ molar ratio in formulation, which was 2.15 for the G-RM-5N-0FA. In particular, the strength of the G-RM-5N-0FA cured for 7 days was below $5 \mathrm{MPa}$ [20]. The flexural strength for the 28 day $\mathrm{SiC}$ sludge geopolymers is $4.05 \mathrm{MPa}$ for $0.8 \mathrm{NS} 30 \mathrm{SCS}\left(\mathrm{SiO}_{2} / \mathrm{Al}_{2} \mathrm{O}_{3}\right.$ molar ratio of 1.74), as shown in Figure 2a. A low $\mathrm{SiO}_{2} / \mathrm{Al}_{2} \mathrm{O}_{3}$ molar ratio significantly reduced the strength for 0.8NS30SCS, which is in line with the study from Hu et al. for geopolymer materials [20].

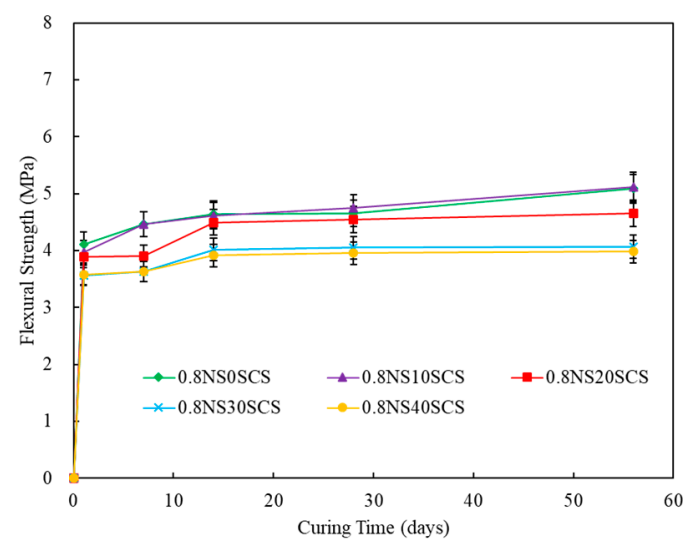

(a)

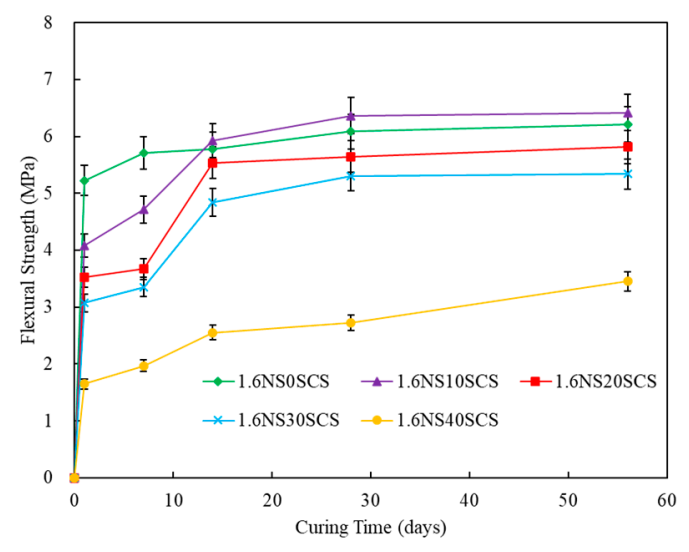

(c)

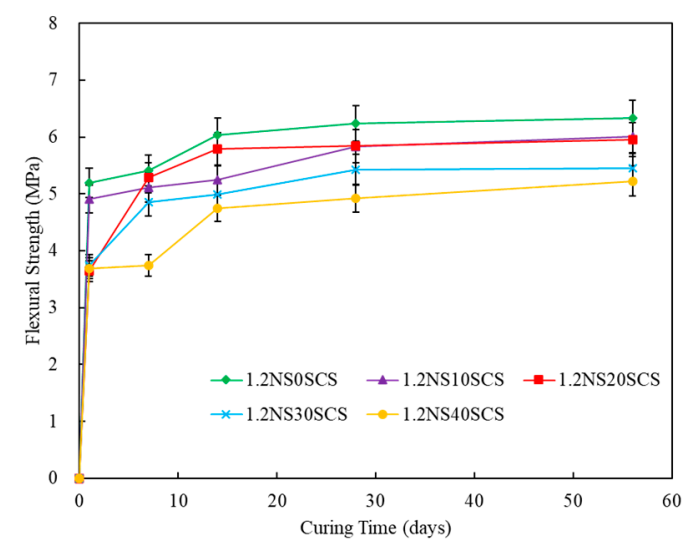

(b)

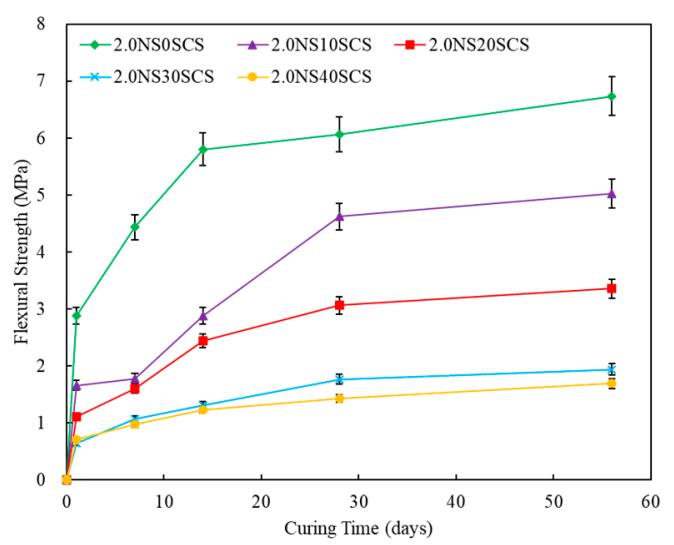

(d)

Figure 2. Flexural strength of geopolymer with $\mathrm{SiC}$ sludge cured for 1-56 days: (a) NS/SS ratio = 0.8; (b) $\mathrm{NS} / \mathrm{SS}$ ratio $=1.2 ;$ (c) NS/SS ratio $=1.6 ;($ d $) \mathrm{NS} / \mathrm{SS}$ ratio $=2.0$.

For the NS/SS ratio of 1.2, the flexural strengths of 1.2NS20SCS, 1.2NS30SCS, and 1.2NS40SCS steadily decreased to $3.64,3.74$, and $3.69 \mathrm{MPa}$ on the first day of curing, respectively (Figure 2b). It is possibly the increase in the $\mathrm{NaOH}$ content, which generated a sufficient amount of " $\mathrm{OH}^{-"}$ " in the system and thus led to the increased solubility. This behavior caused unsatisfactory polycondensation and reduced the formation of amorphously structured geopolymer gels. The high $\mathrm{Na}_{2} \mathrm{O}$ concentration may block the acceleration effect of geopolymer synthesis, leading to slow strength development, which is in line with previous studies for geopolymer materials [21].

In contrast, the increase in the curing time from 1 to 56 days increased the strengths of 1.6NS10SCS and 2.0NS10SCS from 4.08 to $6.42 \mathrm{MPa}$ and from 1.66 to $5.03 \mathrm{MPa}$, respectively (Figure 2c). Increasing the NS/SS ratio promoted the dissolution of the initial solid, which accelerated the geopolymerization reaction and led to the rapid formation of geopolymer network structures. Therefore, the strength increased when the amount of amorphously structured geopolymer gel formed in the geopolymerization system increased. Lo et al. [21] reported that MKGP (MK-based geopolymer) with a 10\% TLWD (TFT-LCD waste glass) replacement level showed the strength of $6.5 \mathrm{MPa}$ with a $\mathrm{S} / \mathrm{N}$ ratio of 1.6. 
The results indicated that strength increased with the NS/SS ratio. Yaghoubi et al. [22] noted that the geopolymer strength was related to the degree of polycondensation, which was strongly influenced by the soluble $\mathrm{SiO}_{4}$ and $\mathrm{AlO}_{4}$ content of the polymer system. A high degree of polycondensation in the Si-O-Al framework structure corresponds to high strength [23]. In addition, the flexural strength of 1.6NS10SCS $\left(\mathrm{SiO}_{2} / \mathrm{Al}_{2} \mathrm{O}_{3}\right.$ molar ratio of 1.51) is also very high, as shown in Figure 2c. This increase in strength could be from the increased $\mathrm{SiO}_{2} / \mathrm{Al}_{2} \mathrm{O}_{3}$ molar ratio. The $\mathrm{SiO}_{2} / \mathrm{Al}_{2} \mathrm{O}_{3}$ molar ratio has a definite effect on strength, increasing the strength to $6.37 \mathrm{MPa}$. In addition, Rahman et al. [14] also noted that the increase in flexural strength due to simultaneous inclusion of silica and silicon carbide whiskers indicates that it is possible that silica particles are compatible with the metakaolin-based geopolymers, which is effective in consolidation [14]. However, the flexural strength of 1.6NS40SCS with a curing age of 28 days decreased to $2.73 \mathrm{MPa}\left(\mathrm{SiO}_{2} / \mathrm{Al}_{2} \mathrm{O}_{3}\right.$ molar ratio of 2.89), as shown in Figure 2c. With increasing $\mathrm{SiC}$ sludge content in the geopolymer, the $\mathrm{SiO}_{2} / \mathrm{Al}_{2} \mathrm{O}_{3}$ molar ratio increases, but the amounts of dissolved silica and alumina from $\mathrm{MK}$ are limited due to precipitation of geopolymer gels around the surface of SCS particles. A greater amount of SiC sludge (over 20\%) may block the synergistic effect of SCS and MK. Hu et al. [20] reported about when the FA (fly ash) content was $100 \mathrm{wt} \%$, and the strength of the FA-based geopolymer with a curing age of 28 days was only $5 \mathrm{MPa}$ $\left(\mathrm{SiO}_{2} / \mathrm{Al}_{2} \mathrm{O}_{3}\right.$ molar ratio of 4.38).

\subsection{DTA/TG of Geopolymers with SiC Sludge}

Figure 3 displays the effects of the geopolymers with $\mathrm{SiC}$ sludge on the DTA/TG results. According to the weight loss of the samples during heating, all the processes of DTA/TG results are categorized into Stages I, II, and III. The first peak at approximately $230^{\circ} \mathrm{C}$ was associated with the loss of carbonate salt. Almost all the weight loss at the second peak, which occurred from $230{ }^{\circ} \mathrm{C}$ to $400{ }^{\circ} \mathrm{C}$, was likely due to the dehydration of the macropore structure of the material [21]. The third peak, which occurred from $400{ }^{\circ} \mathrm{C}$ to $750{ }^{\circ} \mathrm{C}$, was mainly related to the loss of the amorphous composition and dehydration of the geopolymer gel [21,24]. On the first day of curing, the weight loss percentages of 0.8NS0SCS, 0.8NS10SCS, 0.8NS20SCS, and 0.8NS30SCS were 10.21, 10.20, 10.09, and $10.08 \mathrm{wt} \%$, respectively (Table 3). The amounts of dissolved silica and alumina from MK are limited due to precipitation of geopolymer gels around the surface of SCS particles, thus reducing the macropore structure. Therefore, the weight loss of $0.8 \mathrm{NS} 40 \mathrm{SCS}$ was $10.06 \mathrm{wt} \%$. The geopolymers with high replacement levels of SiC sludge generated an inadequate amount of leading precursors, thus limiting the polycondensation process. Therefore, the weight loss percentage of 0.8 NS40SCS from 400 to $750{ }^{\circ} \mathrm{C}$ decreased to $1.95 \%$, as shown in Table 3.

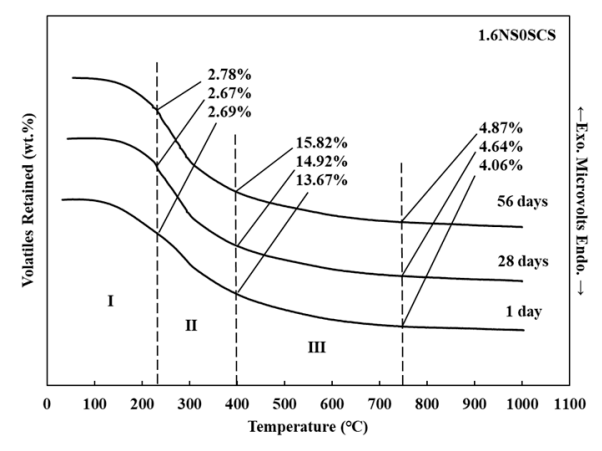

(a)

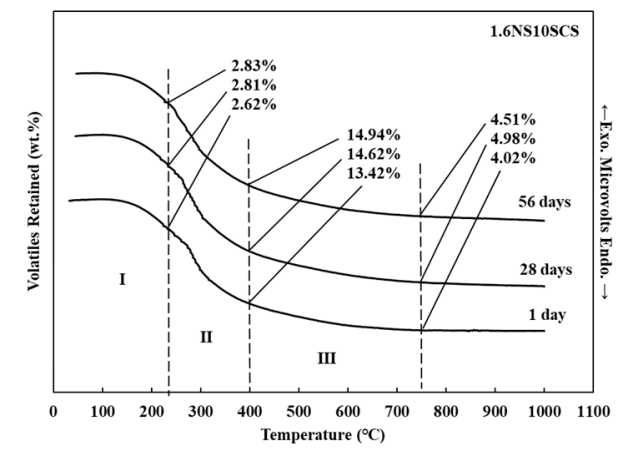

(b)

Figure 3. Cont. 


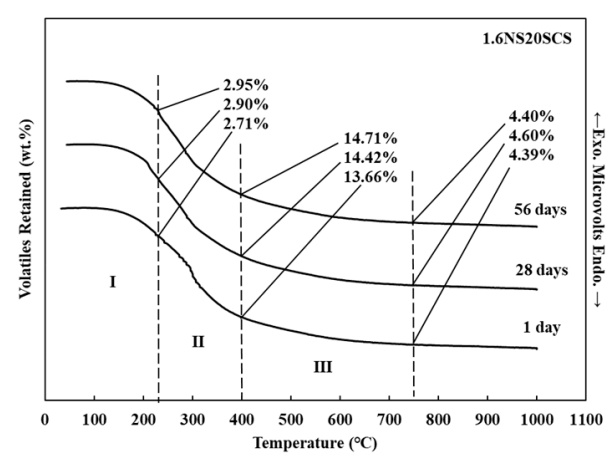

(c)

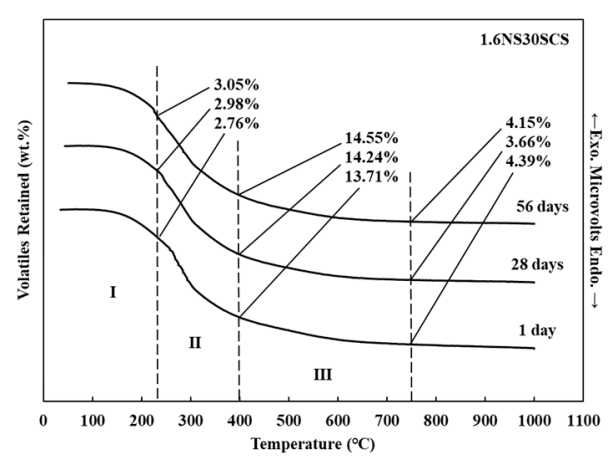

(d)

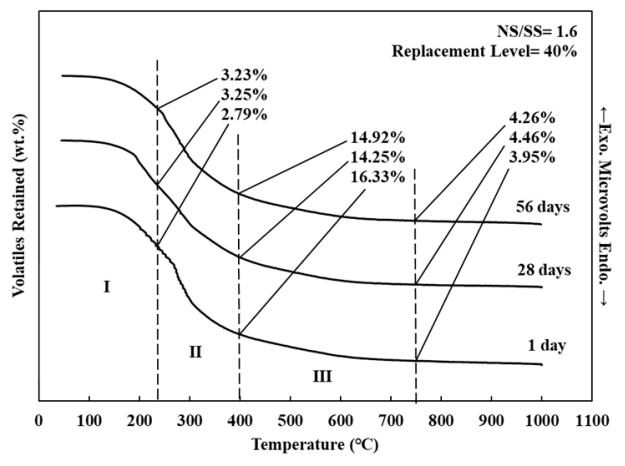

(e)

Figure 3. The DTA/TG results of the geopolymers with SiC sludge and NS/SS ratio of 1.6, during heating: (a) replacement level $=0 \%$; (b) replacement level $=10 \%$; (c) replacement level $=20 \%$; (d) replacement level $=30 \%$; (e) replacement level $=40 \%$.

When the NS/SS ratio increased from 0.8 to 1.6, the weight loss percentage of 1.6NS10SCS was $13.42 \%$ in a temperature range of $230-400^{\circ} \mathrm{C}$, as depicted in Figure $3 \mathrm{~b}$. The high NS/SS ratio prompted the dissolution of the initial solid and consequently promoted the geopolymerization reaction, which caused the rapid formation of 3D silico-aluminate structures. Furthermore, the synergistic effect between the SCS and the MK was assigned to the promotion of the geopolymerization reaction, which caused the oligomers to form integral geopolymer gels. Therefore, the structural strength increased with an increase in the amount of amorphously structured geopolymeric gel in the geopolymerization system. According to the results, the weight loss percentage of 1.6NS10SCS increased to $14.94 \%$ after 56 days of curing. Furthermore, low weight loss occurred in the temperature range of $400-750{ }^{\circ} \mathrm{C}$. The weight loss percentages of 1.6NS0SCS, 1.6NS10SCS, 1.6NS20SCS, 1.6NS30SCS, and 1.6NS40SCS were 4.87, $4.51,4.40,4.15$, and 4.26 wt \%, respectively (Figure 3a-e). 
Table 3. Weight loss of the geopolymers with $\mathrm{SiC}$ sludge during heating from ambient temperature to $1000{ }^{\circ} \mathrm{C}(\mathrm{NS} / \mathrm{SS}$ ratio $=0.8$ and 1.2$)$.

\begin{tabular}{|c|c|c|c|c|c|}
\hline \multirow{2}{*}{ Samples } & \multirow{2}{*}{ NS/SS } & \multirow{2}{*}{ Curing Time (Days) } & \multicolumn{3}{|c|}{ Temperature $\left({ }^{\circ} \mathrm{C}\right)$} \\
\hline & & & $50-230$ & $230-400$ & $400-750$ \\
\hline \multirow{3}{*}{$0.8 \mathrm{NSOSCS}$} & & 1 & 2.58 & 10.21 & 2.61 \\
\hline & & 28 & 3.70 & 11.81 & 4.24 \\
\hline & & 56 & 4.37 & 12.36 & 4.68 \\
\hline \multirow{3}{*}{ 0.8NS10SCS } & & 1 & 2.77 & 10.20 & 2.35 \\
\hline & & 28 & 3.83 & 11.69 & 4.24 \\
\hline & & 56 & 4.42 & 12.36 & 4.62 \\
\hline \multirow{4}{*}{$0.8 \mathrm{NS} 20 \mathrm{SCS}$} & & 1 & 3.72 & 10.09 & 2.33 \\
\hline & 0.8 & 28 & 3.83 & 11.66 & 4.03 \\
\hline & & 56 & 4.48 & 12.32 & 4.24 \\
\hline & & 1 & 3.49 & 10.08 & 2.22 \\
\hline \multirow[t]{2}{*}{ 0.8NS30SCS } & & 28 & 3.94 & 11.64 & 3.68 \\
\hline & & 56 & 4.48 & 12.24 & 4.03 \\
\hline & & 1 & 3.49 & 10.06 & 1.95 \\
\hline \multirow[t]{2}{*}{$0.8 \mathrm{NS} 40 \mathrm{SCS}$} & & 28 & 3.94 & 11.59 & 3.52 \\
\hline & & 56 & 4.50 & 12.21 & 3.68 \\
\hline \multirow{3}{*}{ 1.2NSOSCS } & & 1 & 3.49 & 10.97 & 2.73 \\
\hline & & 28 & 3.94 & 12.51 & 4.09 \\
\hline & & 56 & 4.51 & 12.96 & 4.77 \\
\hline \multirow{3}{*}{ 1.2NS10SCS } & & 1 & 3.49 & 10.96 & 2.72 \\
\hline & & 28 & 4.14 & 12.49 & 4.07 \\
\hline & & 56 & 4.55 & 12.93 & 4.34 \\
\hline \multirow{4}{*}{$1.2 \mathrm{NS} 20 \mathrm{SCS}$} & & 1 & 3.52 & 10.93 & 2.64 \\
\hline & 1.2 & 28 & 4.21 & 12.46 & 3.99 \\
\hline & & 56 & 4.55 & 12.86 & 4.33 \\
\hline & & 1 & 3.52 & 10.92 & 2.64 \\
\hline \multirow[t]{2}{*}{ 1.2NS30SCS } & & 28 & 4.25 & 12.42 & 3.96 \\
\hline & & 56 & 4.61 & 12.75 & 4.21 \\
\hline \multirow{3}{*}{$1.2 \mathrm{NS} 40 \mathrm{SCS}$} & & 1 & 3.58 & 10.88 & 2.57 \\
\hline & & 28 & 4.25 & 12.39 & 3.90 \\
\hline & & 56 & 4.61 & 12.65 & 4.14 \\
\hline
\end{tabular}

\section{4. ${ }^{29}$ Si NMR Spectra and Deconvolutions of Geopolymers with SiC Sludge}

To further validate the evolution of chemical reactions in geopolymerization with SiC sludge, ${ }^{29} \mathrm{Si}$ NMR analyses were conducted on the geopolymer samples. The ${ }^{29} \mathrm{Si} \mathrm{NMR}$ spectra analysis enables the short-range ordering and molecular structure in the geopolymerization reaction to be determined [25]. In the initial stage, geopolymerization involved the release of the silicate derivatives $\left(\mathrm{Q}^{1}, \mathrm{Q}^{2}\right.$, and $\left.\mathrm{Q}^{3}\right)$ in the solution by alkaline activation. Here, the resonances of $\mathrm{Q}^{1}, \mathrm{Q}^{2}$, and $\mathrm{Q}^{3}$ resonate at approximately $-79,-85$, and $-95 \mathrm{ppm}$, respectively, and the resonance of $\mathrm{Q}^{4}$ is the same as the $\mathrm{Q}^{4}(0 \mathrm{Al})$ of the geopolymer gel [26]. The detailed reaction mechanism is discussed in the following sections. The resonance of a $\mathrm{Q}^{4}(\mathrm{mAl})(0 \leq \mathrm{m} \leq 4)$ center with the replacement of each aluminum by silicon is approximately $-5 \mathrm{ppm}$, with chemical shifts at $-84,-89,-93,-99$, and $-107 \mathrm{ppm}$ that correspond to $\mathrm{Q}^{4}(4 \mathrm{Al}), \mathrm{Q}^{4}(3 \mathrm{Al}), \mathrm{Q}^{4}(2 \mathrm{Al}), \mathrm{Q}^{4}(1 \mathrm{Al})$, and $\mathrm{Q}^{4}(0 \mathrm{Al})$, respectively [25].

Figure 4 displays the ${ }^{29} \mathrm{Si}$ NMR spectra and deconvolutions of $\mathrm{SiC}$ sludge geopolymers with 28 days of curing. After 28 days of curing, the spectra of $0.8 \mathrm{NSOSCS}$ revealed a high percentage of $\mathrm{Q}^{4}(3 \mathrm{Al})$, thus indicating a high initial level of aluminosilicate. For the ${ }^{29} \mathrm{Si}$ NMR deconvolution of $0.8 \mathrm{NSOSCS}$, the percentages of $\mathrm{Q}^{4}(3 \mathrm{Al}), \mathrm{Q}^{4}(2 \mathrm{Al})$, and $\mathrm{Q}^{4}(1 \mathrm{Al})$ were $34.32 \%, 16.06 \%$, and $7.06 \%$, respectively. However, geopolymers with high replacement levels of $\mathrm{SiC}$ sludge generated an inadequate amount of leading precursors, thus limiting the polycondensation process. For example, for $0.8 \mathrm{NS} 40 \mathrm{SCS}$, the percentages of $\mathrm{Q}^{4}(3 \mathrm{Al}), \mathrm{Q}^{4}(2 \mathrm{Al})$, and $\mathrm{Q}^{4}(1 \mathrm{Al})$ were $29.59 \%, 24.91 \%$, and $20.05 \%$, respectively. On the 28 th day of curing, the spectra of $0.8 \mathrm{NS} 40 \mathrm{SCS}$ revealed a high percentage of $\mathrm{Q}^{4}(0 \mathrm{Al})$, thus indicating the formation 
of sodium silicate glass from the unreacted $\mathrm{Na}_{2} \mathrm{SiO}_{3}$ activator [27]. This result indicates that $\mathrm{SiC}$ sludge inhibits geopolymerization reactions.

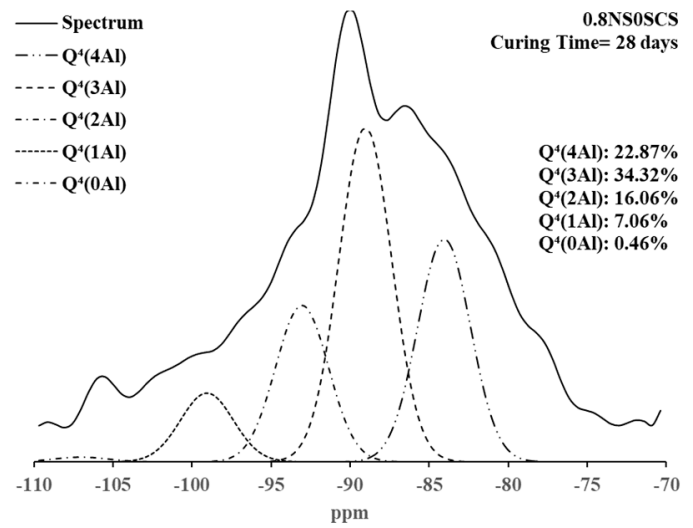

(a)

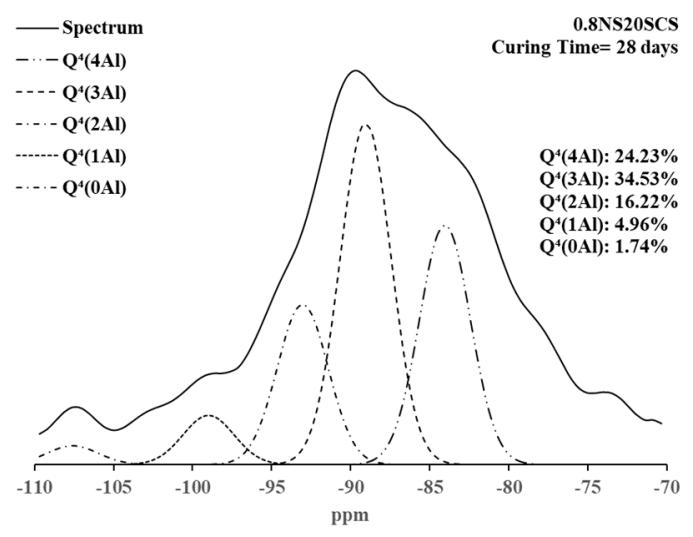

(c)

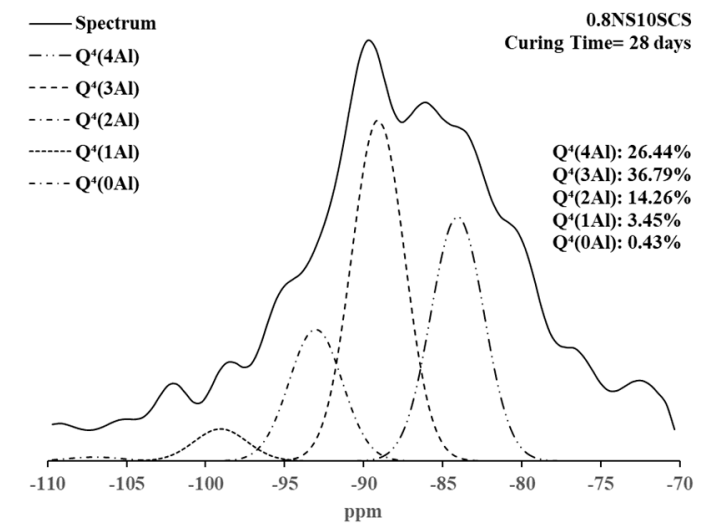

(b)

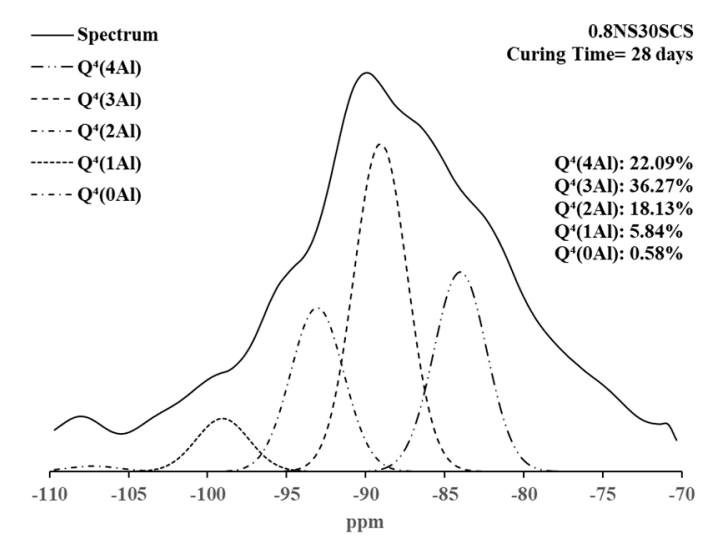

(d)

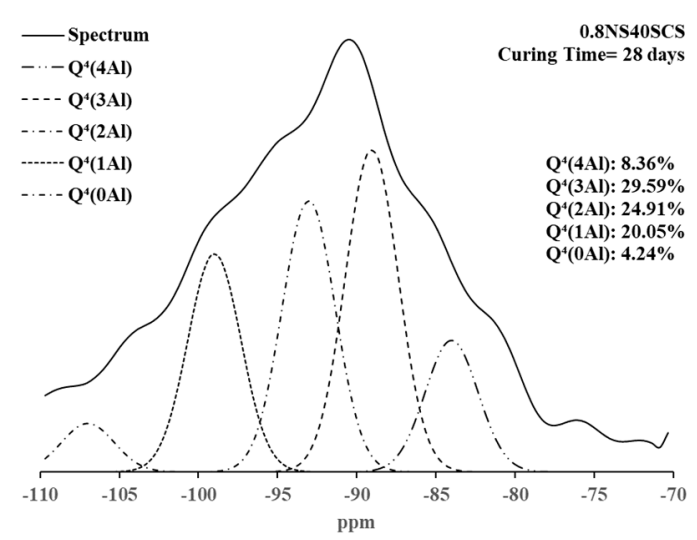

(e)

Figure 4. The ${ }^{29} \mathrm{Si}$ NMR spectra and deconvolutions of SiC sludge geopolymers at Curing Time $=28$ day, and NS/SS ratio of 0.8 : (a) replacement level $=0 \%$; (b) replacement level $=10 \%$; (c) replacement level $=20 \%$; (d) replacement level $=30 \%$; (e) replacement level $=40 \%$.

Figure 5 depicts the ${ }^{29} \mathrm{Si}$ NMR spectra deconvolution obtained for the geopolymers with $\mathrm{SiC}$ sludge over 28 days of curing. After the 28th day of curing for 1.2NS10SCS, the percentages of $\mathrm{Q}^{4}(3 \mathrm{Al}), \mathrm{Q}^{4}(2 \mathrm{Al})$, and $\mathrm{Q}^{4}(1 \mathrm{Al})$ were $33.71 \%, 22.47 \%$, and $9.03 \%$, respectively. The results revealed that when the NS/SS ratio was relatively low, an increase in the $\mathrm{NaOH}$ content caused the generation of a 
sufficient amount of $\mathrm{OH}^{-}$in the system to increase the solubility, thus limiting the polycondensation process. This behavior caused a decrease in the formation of amorphously structured geopolymer gels. Therefore, the $\mathrm{Q}^{4}(3 \mathrm{Al}), \mathrm{Q}^{4}(2 \mathrm{Al})$, and $\mathrm{Q}^{4}(1 \mathrm{Al})$ contents of $1.2 \mathrm{NS} 10 \mathrm{SCS}$ slowly increased, as displayed in Figure $5 \mathrm{~b}$. When the NS/SS ratio increased to 1.6, 1.6NS10SCS exhibited high percentages of $\mathrm{Q}^{4}(3 \mathrm{Al})$ $(33.63 \%), \mathrm{Q}^{4}(2 \mathrm{Al})(23.92 \%)$, and $\mathrm{Q}^{4}(1 \mathrm{Al})(9.70 \%)$, as illustrated in Figure $6 \mathrm{~b}$. Because of a synergistic effect between silicon carbide sludge and metakaolin, the silica and alumina of metakaolin were dominant in the geopolymerization reaction, and the addition of silicon carbide sludge, which had silica was provided more reaction paths. Wan et al. [28] indicated that geopolymers with high compressive strengths have high percentages of $\mathrm{Q}^{4}(3 \mathrm{Al}), \mathrm{Q}^{4}(2 \mathrm{Al})$, and $\mathrm{Q}^{4}(1 \mathrm{Al})$, and were possibly $\mathrm{N}-\mathrm{A}-\mathrm{S}-\mathrm{H}$ gels [28]. The percentages of $\mathrm{Q}^{4}(3 \mathrm{Al}, 2 \mathrm{Al}$, and $1 \mathrm{Al})$ silicon centers in the ${ }^{29} \mathrm{Si} \mathrm{NMR}$ spectra increased, thus indicating the formation of an increased number of tetrahedral aluminum-linking sites with tetrahedral silicon (Figure 6).

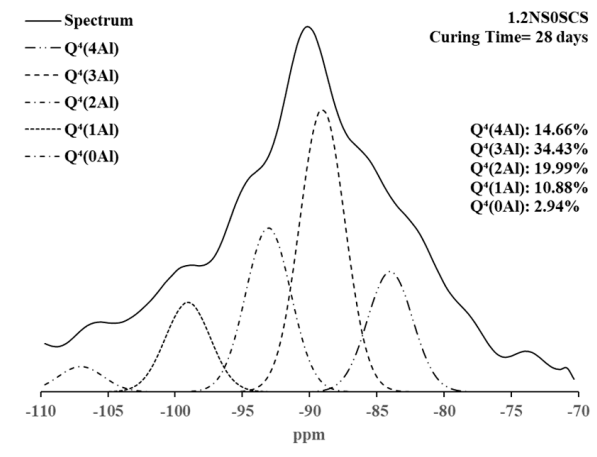

(a)

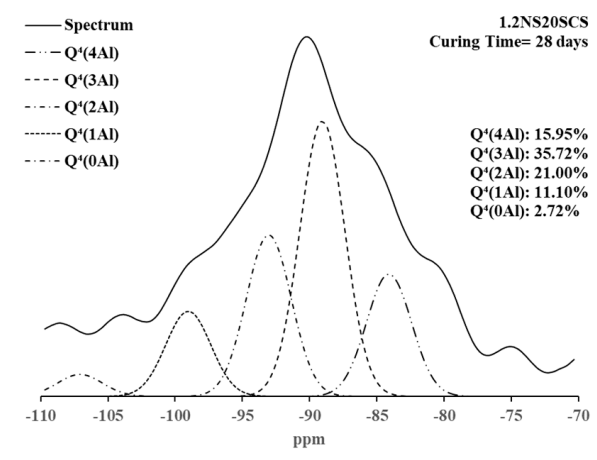

(c)

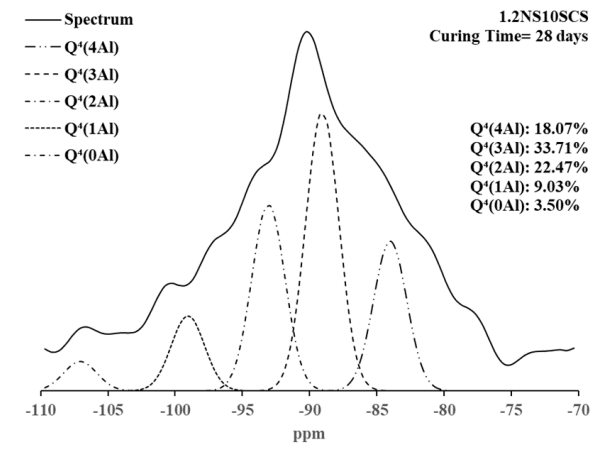

(b)

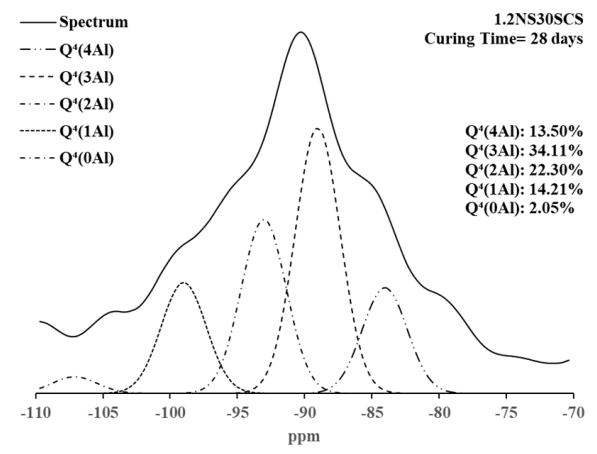

(d)

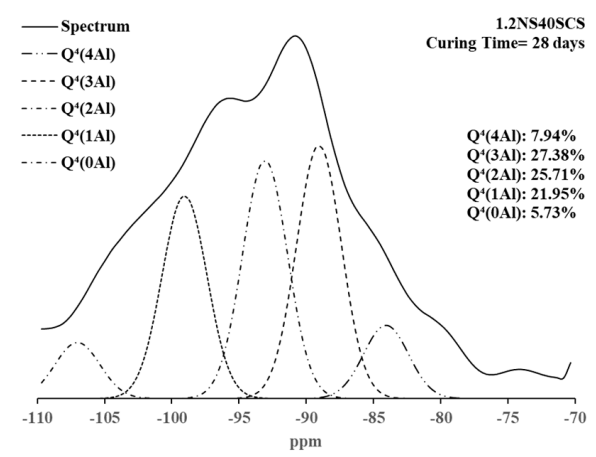

(e)

Figure 5. The ${ }^{29} \mathrm{Si}$ NMR spectra and deconvolutions of $\mathrm{SiC}$ sludge geopolymers at Curing Time $=28$ day, and NS/SS ratio of 1.2: (a) replacement level $=0 \%$; (b) replacement level $=10 \%$; (c) replacement level $=20 \%$; (d) replacement level $=30 \%$; (e) replacement level $=40 \%$. 


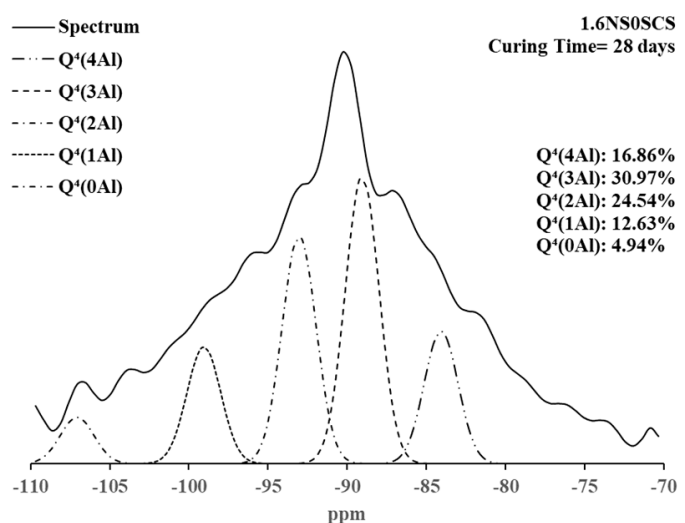

(a)

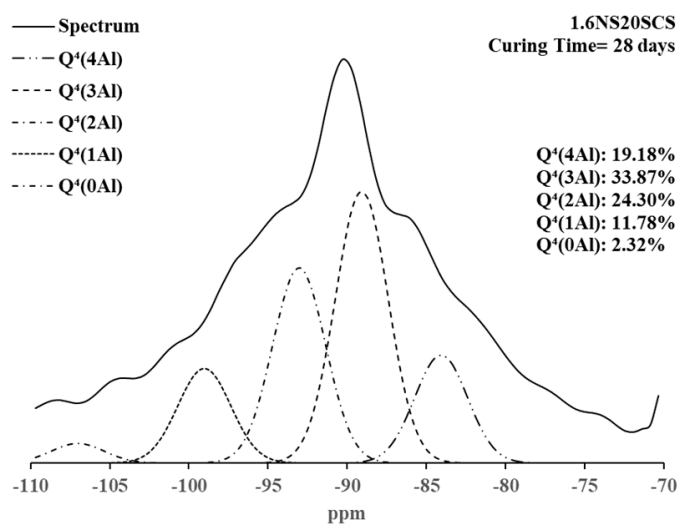

(c)

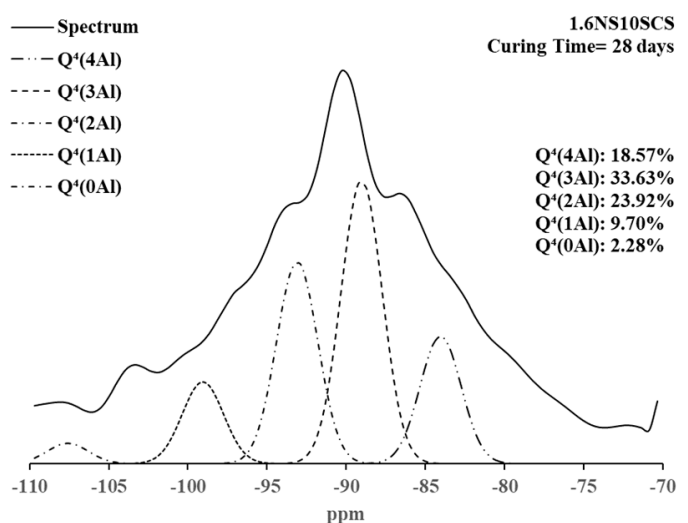

(b)

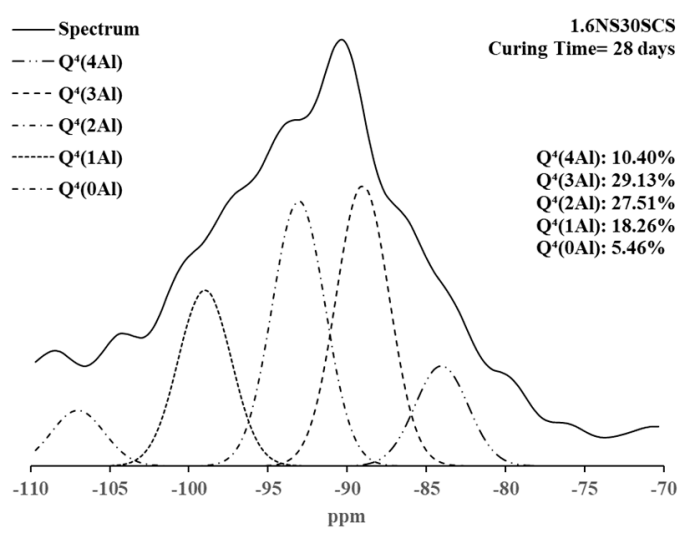

(d)

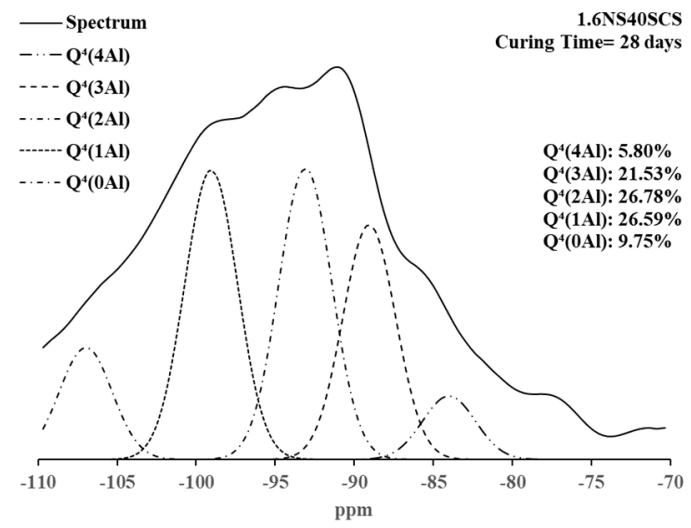

(e)

Figure 6. The ${ }^{29} \mathrm{Si} \mathrm{NMR}$ spectra and deconvolutions of SiC sludge geopolymers at Curing Time $=28$ day, and NS/SS ratio of 1.6: (a) replacement level $=0 \%$; (b) replacement level $=10 \%$; (c) replacement level $=20 \%$; (d) replacement level $=30 \%$; (e) replacement level $=40 \%$.

\section{Discussion}

The geopolymerization process of geopolymers with $\mathrm{SiC}$ sludge is illustrated in Figure 7. In steps 1 and 2, the active components of metakaolin and $\mathrm{SiC}$ sludge particles were dissolved to form monosilicates $\left(\mathrm{Q}^{0}\right)$ that were linked to the end groups $\left(\mathrm{Q}^{1}\right)$, middle chain groups $\left(\mathrm{Q}^{2}\right)$, layers and branching sites $\left(\mathrm{Q}^{3}\right)$, and $\left[\mathrm{SiO}_{4}\right]$ and $\left[\mathrm{AlO}_{4}\right]$ tetrahedrons in the AASs. In step 3, primary particles of oligomeric gel were formed by the oligomers through the polycondensation reaction in the AASs. In step 4, the oligomers 
were polycondensed to form geopolymerization gels. In step 5 , the polymers were polycondensed and accumulated around the unreacted $\mathrm{SiC}$ sludge surface to form 3D networks $\left(\mathrm{Q}^{4}\right)$.

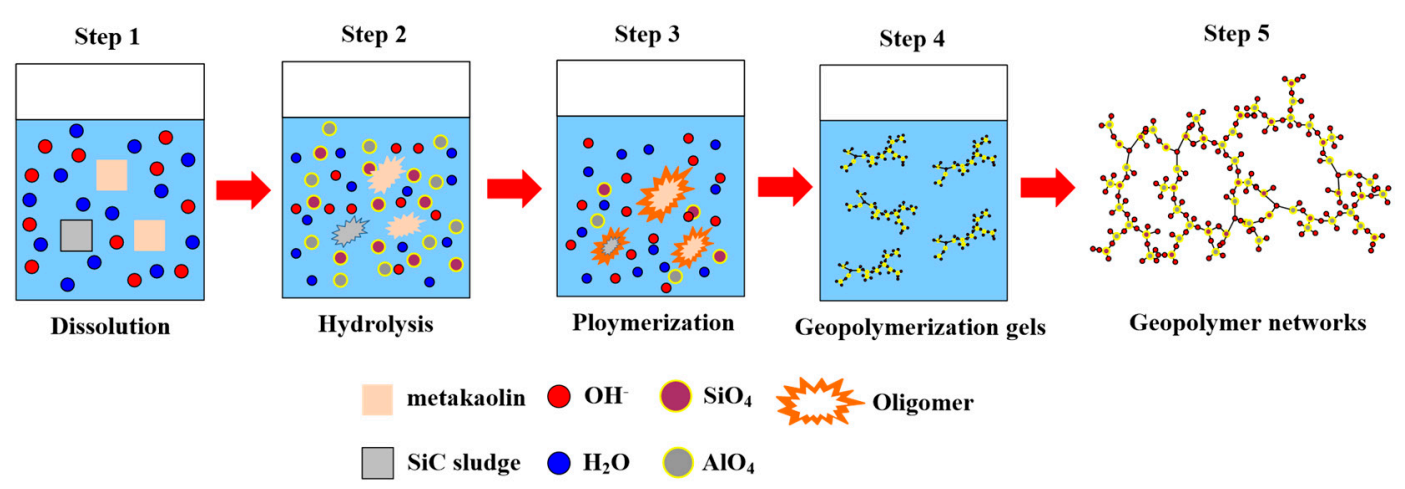

Figure 7. The geopolymerization process of geopolymers with $\mathrm{SiC}$ sludge.

At an early curing time, for 0.8 NSOSCS, the sum of the silicate derivatives $\left(Q^{1}, Q^{2}\right.$, and $\left.Q^{3}\right)$ was $13.59 \%$ (Table 4). After 28 days of curing, the percentage of silicate derivatives increased to $19.23 \%$, as shown in Table 4. The results revealed that when the NS/SS ratio was relatively low, an increase in the $\mathrm{NaOH}$ content caused the generation of sufficient $\mathrm{OH}^{-}$in the system to increase the solubility. This solubility increase caused hindrance in polycondensation, as indicated by the heat evolution rate and DTA/TG results (Figure 1 and Table 3). The inhibition of polycondensation reduced the mechanical strength (Figure 2). An increase in the NS/SS ratio promoted the dissolution of the initial solid, thus accelerating the geopolymerization reaction and leading to the rapid formation of geopolymer network structures. During the geopolymerization reaction, silicate derivatives were transformed into geopolymer gels. Therefore, the weight percentage of the silicate derivatives of 1.6NSOSCS decreased to $10.06 \%$ after 28 days of curing. Furthermore, the synergistic effect between the SCS and the MK was assigned to the promotion of the geopolymerization reaction, which caused the flexural strength of 1.6NS10SCS to increase to $6.42 \mathrm{MPa}$ after 28 days of curing. First, the silica and alumina of metakaolin were dominant in the geopolymerization reaction, and the addition of silicon carbide sludge, which had silica, was provided more reaction paths. In addition, Rahman et al. [14] also noted that given the increase in flexural strength due to simultaneous inclusion of silica and silicon carbide whiskers, it is possible that silica particles are compatible with the metakaolin-based geopolymers, which is effective in consolidation [14]. According to the DTA/TG results, the weight loss percentage of 1.6NS10SCS increased to $14.62 \%$ from 400 to $750{ }^{\circ} \mathrm{C}$, as shown in Figure $3 \mathrm{~b}$. This fact implies that the synergistic effect promoted the oligomers to combine and form integral geopolymer gels [20].

However, geopolymers with high replacement levels of $\mathrm{SiC}$ sludge generated an inadequate amount of leading precursors, thus limiting the polycondensation process. For example, for 1.6NS30SCS and 1.6NS40SCS, the weight percentages of silicate derivatives $\left(\mathrm{Q}^{1}, \mathrm{Q}^{2}\right.$, and $\left.\mathrm{Q}^{3}\right)$ were $9.81 \%$ and $9.13 \%$, respectively, as presented in Table 4. In steps 1 and 2, $\mathrm{SiC}$ sludge dissolves to release $\mathrm{Al}^{3+}$ and $\mathrm{Si}^{4+}$, which are hydrolyzed into $\left[\mathrm{AlO}_{4}\right]$ and $\left[\mathrm{SiO}_{4}\right]$ tetrahedrons, respectively, immediately after contact with the AASs. The amounts of dissolved silica and alumina from MK are limited due to precipitations of geopolymer gels around the surface of SCS particles, which caused the number of $\left[\mathrm{SiO}_{4}\right]$ and $\left[\mathrm{AlO}_{4}\right]$ tetrahedrons in the system to be low. Thus, the amount of oligomeric gel was low. Because the N-A-S-H gels activated by the sodium silicate solution required an increased amount of oligomeric gel, the rate of the geopolymerization reaction decreased. Therefore, the heat evolution duration of the second exothermic peak increased from 26.15 to $33.32 \mathrm{~h}$ as the replacement levels of SiC sludge increased from $30 \%$ to $40 \%$ (1.6NS30SCS and 1.6NS40SCS), as shown in Figure 1c. Additionally, the flexural strengths of 1.6NS30SCS and 1.6NS40SCS were 5.31 MPa and 2.73 MPa, respectively (Figure 2c). This result indicated that a relatively high $\mathrm{SiC}$ sludge content (more than 20\%) might block the synergistic effect between SCS and MK, which is confirmed by the heat evolution rate, DTA/TG results, and ${ }^{29}$ Si MAS NMR analyses. This is consistent with the SEM images results of previous studies [29] that the 
amorphous gel products had gradually filled the pores of the $\mathrm{SiC}$ sludge-based geopolymer, resulting in an increase in density and compressive strength of the geopolymer structure [29]. The synergistic effect of the SiC sludge and MK promoted the reaction progression, which caused increasing amounts of amorphously structured geopolymeric gels in the geopolymerized system [29]. Then, the unreacted $\mathrm{SiC}$ sludge was in the form of uniform plate particles [29]. In summary, this study demonstrated that this renders $\mathrm{SiC}$ sludge as promising additives for the production of metakaolin-based geopolymers. As a structural material, the $\mathrm{SiC}$ sludge-based geopolymer is a potential replacement material for OPC.

Table 4. ${ }^{29}$ Si MAS NMR spectral deconvolution of the silicate derivatives (Curing Time $=1$ day and 28 days).

\begin{tabular}{|c|c|c|c|c|c|c|c|c|c|}
\hline \multirow{2}{*}{ Samples } & \multirow{2}{*}{ Curing Time } & \multicolumn{3}{|c|}{ Silicate Derivatives (\%) } & \multicolumn{5}{|c|}{ Deconvoluted Fractions of Silicon Centers (\%) } \\
\hline & & $\mathbf{Q}^{1}$ & $\mathrm{Q}^{2}$ & $\mathrm{Q}^{3}$ & $\mathrm{Q}^{4}(\mathrm{OAl})$ & $\mathrm{Q}^{4}(\mathbf{A} \mathrm{l})$ & $\mathrm{Q}^{4}(2 \mathrm{Al})$ & $\mathrm{Q}^{4}(3 \mathrm{Al})$ & $\mathrm{Q}^{4}(4 \mathrm{Al})$ \\
\hline $0.8 \mathrm{NSOSCS}$ & & 10.07 & 1.41 & 2.11 & 0.66 & 5.62 & 16.17 & 35.85 & 28.11 \\
\hline $0.8 \mathrm{NS} 10 \mathrm{SCS}$ & & 8.72 & 2.53 & 2.30 & 1.30 & 7.59 & 18.64 & 33.82 & 25.10 \\
\hline $0.8 \mathrm{NS} 20 \mathrm{SCS}$ & 1 day & 9.22 & 2.16 & 2.55 & 2.85 & 5.89 & 19.23 & 34.15 & 23.95 \\
\hline $0.8 \mathrm{NS} 30 \mathrm{SCS}$ & & 4.36 & 3.11 & 2.08 & 4.12 & 10.79 & 21.79 & 34.24 & 19.51 \\
\hline $0.8 \mathrm{NS} 40 \mathrm{SCS}$ & & 1.56 & 3.31 & 4.28 & 3.43 & 17.66 & 25.46 & 26.38 & 17.92 \\
\hline $0.8 \mathrm{NS} 0 \mathrm{SCS}$ & & 10.22 & 4.62 & 4.39 & 0.46 & 7.06 & 16.06 & 34.32 & 22.87 \\
\hline 0.8NS10SCS & & 10.58 & 5.06 & 2.99 & 0.43 & 3.45 & 14.26 & 36.79 & 26.44 \\
\hline $0.8 \mathrm{NS} 20 \mathrm{SCS}$ & 28 days & 11.26 & 4.77 & 2.29 & 1.74 & 4.96 & 16.22 & 34.53 & 24.23 \\
\hline $0.8 \mathrm{NS} 30 \mathrm{SCS}$ & & 10.42 & 4.59 & 2.08 & 0.58 & 5.84 & 18.13 & 36.27 & 22.09 \\
\hline $0.8 \mathrm{NS} 40 \mathrm{SCS}$ & & 4.13 & 3.90 & 4.82 & 4.24 & 20.05 & 24.91 & 29.59 & 8.36 \\
\hline $1.2 \mathrm{NS} 0 \mathrm{SCS}$ & & 7.74 & 3.61 & 3.10 & 2.45 & 9.81 & 20.39 & 33.55 & 19.35 \\
\hline 1.2NS10SCS & & 8.05 & 4.14 & 2.76 & 1.73 & 8.05 & 20.25 & 34.98 & 20.04 \\
\hline $1.2 \mathrm{NS} 20 \mathrm{SCS}$ & 1 day & 7.17 & 4.01 & 3.59 & 3.57 & 9.50 & 20.68 & 34.18 & 17.30 \\
\hline 1.2NS30SCS & & 3.94 & 5.03 & 4.81 & 3.94 & 10.36 & 24.02 & 32.26 & 15.64 \\
\hline $1.2 \mathrm{NS} 40 \mathrm{SCS}$ & & 3.08 & 3.74 & 4.17 & 6.18 & 21.53 & 25.71 & 26.37 & 9.22 \\
\hline 1.2NSOSCS & & 6.44 & 5.77 & 4.89 & 2.94 & 10.88 & 19.99 & 34.43 & 14.66 \\
\hline 1.2NS10SCS & & 6.17 & 3.97 & 3.08 & 3.50 & 9.03 & 22.47 & 33.71 & 18.07 \\
\hline $1.2 \mathrm{NS} 20 \mathrm{SCS}$ & 28 days & 2.41 & 6.03 & 5.07 & 2.72 & 11.10 & 21.00 & 35.72 & 15.95 \\
\hline 1.2NS30SCS & & 5.59 & 3.30 & 4.94 & 2.05 & 14.21 & 22.30 & 34.11 & 13.50 \\
\hline 1.2NS40SCS & & 0.84 & 4.60 & 5.85 & 5.73 & 21.95 & 25.71 & 27.38 & 7.94 \\
\hline 1.6NSOSCS & & 5.00 & 3.81 & 3.81 & 3.40 & 13.58 & 25.66 & 30.69 & 14.05 \\
\hline 1.6NS10SCS & & 5.87 & 4.51 & 4.96 & 4.81 & 14.46 & 23.80 & 31.50 & 10.09 \\
\hline 1.6NS20SCS & 1 day & 4.91 & 5.40 & 3.93 & 6.62 & 16.00 & 27.18 & 29.37 & 6.59 \\
\hline 1.6NS30SCS & & 2.23 & 3.57 & 4.01 & 6.64 & 18.05 & 27.85 & 29.63 & 8.02 \\
\hline 1.6NS40SCS & & 0.89 & 2.23 & 6.01 & 9.19 & 27.82 & 28.93 & 17.81 & 7.12 \\
\hline 1.6NSOSCS & & 5.03 & 1.76 & 3.27 & 4.94 & 12.63 & 24.54 & 30.97 & 16.86 \\
\hline 1.6NS10SCS & & 5.13 & 3.50 & 3.27 & 2.28 & 9.70 & 23.92 & 33.63 & 18.57 \\
\hline 1.6NS20SCS & 28 days & 2.41 & 3.07 & 3.07 & 2.32 & 11.78 & 24.30 & 33.87 & 19.18 \\
\hline 1.6NS30SCS & & 0.92 & 4.16 & 4.16 & 5.46 & 18.26 & 27.51 & 29.13 & 10.40 \\
\hline 1.6NS40SCS & & 1.69 & 3.74 & 4.12 & 9.75 & 26.59 & 26.78 & 21.53 & 5.80 \\
\hline
\end{tabular}

\section{Conclusions}

The present study investigated the effects of different $\mathrm{SiC}$ sludge contents and alkaline activator solutions on the geopolymer reaction and microstructures of metakaolin-based geopolymers subjected to different curing times. The geopolymer with the optimal SiC sludge replacement level and NS/SS ratio contained a high heat evolution value $(990.6 \mathrm{~W} / \mathrm{g})$, excellent mechanical properties (6.42 MPa), and high deconvolution percentages of $\mathrm{Q}^{4}(3 \mathrm{Al}, 2 \mathrm{Al}$, and $1 \mathrm{Al})$. The conclusions can be summarized as follows. The high $\mathrm{NaOH}$ concentration prompted the dissolution of the initial solid in the alkaline activator, which caused the first exothermal peaks to be more intense. The 1.6NS10SCS $\left(\mathrm{SiO}_{2} / \mathrm{Al}_{2} \mathrm{O}_{3}\right.$ molar ratio of 1.51) had favorable mechanical strength due to an increasing $\mathrm{SiO}_{2} / \mathrm{Al}_{2} \mathrm{O}_{3}$ molar ratio and a synergistic effect between the $\mathrm{SiC}$ sludge and the metakaolin. The geopolymers with high replacement levels of $\mathrm{SiC}$ sludge not only contained dissolved silica and alumina from metakaolin but also underwent polycondensation on a geopolymer reaction of $\mathrm{SiC}$ sludge-based geopolymers. A greater amount of $\mathrm{SiC}$ sludge (over $20 \%$ ) may block the synergistic effect between the $\mathrm{SiC}$ sludge and metakaolin. The results of this study have shown that a geopolymer with an optimal SiC-sludge 
replacement level and NS/SS ratio expresses a synergistic effect that allows an improvement of both the geopolymer reaction and the strength of metakaolin-based geopolymers. This renders $\mathrm{SiC}$ sludge as promising additives for the production of metakaolin-based geopolymers. For future work, we expect to analyze other important properties of SiC sludge-based geopolymers by thermal conductivity, and fire performance, which was a promising alternative as fire resistance materials in the construction industry.

Author Contributions: Writing—original draft preparation, K.-W.L.; writing—review and editing, K.-L.L.; T.-W.C.; W.-T.L.; Y.-W.L. All authors have read and agreed to the published version of the manuscript.

Funding: This research was funded by Ministry of Science and Technology of the Republic of China, Taiwan (Contract No. MOST-109-2221-E-197-012-MY3).

Acknowledgments: The authors thank the Ministry of Science and Technology of the Republic of China, Taiwan, for supporting this research financially.

Conflicts of Interest: The authors declare no conflict of interest.

\section{References}

1. Chowdhury, M.S.; Rahman, K.S.; Chowdhury, T.; Nuthammachot, N.; Techato, K.; Akhtaruzzaman, M.; Tiong, S.K.; Sopian, K.; Amin, N. An overview of solar photovoltaic panels' end-of-life material recycling. Energy Strategy Rev. 2020, 27, 100431. [CrossRef]

2. Yoko, A.; Oshima, Y.S. Recovery of silicon from silicon sludge using supercritical water. J. Supercrit. Fluids 2013, 75, 1-5. [CrossRef]

3. Lan, A.; Liu, C.E.; Yan, H.L.; Yua, H.T.; Li, I.T.; Hsua, H.P.; Lan, C.W. Silicon ingot casting using reusable silicon nitride crucibles made from diamond wire sawing kerf-loss silicon. J. Cryst. Growth 2019, 525, 125184. [CrossRef]

4. Eblagon, F.; Ehrle, B.; Graule, T.; Kuebler, J. Development of siliconnitride/silicon carbide composites for wood-cutting tools. J. Eur. Ceram. Soc. 2007, 27, 419-428. [CrossRef]

5. Tsai, T.H. Silicon sawing waste treatment by electrophoresis and gravitational settling. J. Hazard. Mater. 2011, 189, 526-530. [CrossRef]

6. He, P.G.; Wang, M.R.; Fu, S.; Jia, D.C.; Yan, S.; Yuan, J.K.; Xu, J.H.; Wang, P.F.; Zhou, Y. Effects of Si/Al ratio on the structure and properties of metakaolin based geopolymer. Ceram. Int. 2016, 42, 14416-14422. [CrossRef]

7. Elyamany, H.R.; Elmoaty, A.E.M.A.; Elshaboury, A.M. Magnesium sulfate resistance of geopolymer mortar. Constr. Build. Mater. 2018, 184, 111-127. [CrossRef]

8. Leay, L.; Potts, A.; Donoclift, T. Geopolymers from fly ash and their gamma irradiation. Mater. Lett. 2018, 227, 240-242. [CrossRef]

9. Cui, Y.; Wang, D.; Wang, Y.; Sun, R.; Rui, Y. Effects of the $\mathrm{n}\left(\mathrm{H}_{2} \mathrm{O}: \mathrm{Na}_{2} \mathrm{O}_{\mathrm{eq}}\right)$ ratio on the geopolymerization process and microstructures of fly ash-based geopolymers. J. Non Cryst. Solids 2019, 511, 19-28. [CrossRef]

10. Li, Z.; Zhang, S.; Zuo, Y.; Chen, W.; Ye, G. Chemical deformation of metakaolin based geopolymer. Cem. Concr. Res. 2019, 120, 108-118. [CrossRef]

11. Kolezyn'ski, A.; Kro'1, M.; Zychowicz, M. The structure of geopolymers-Theoretical studies. J. Mol. Struct. 2018, 1163, 465-471. [CrossRef]

12. Yusuf, M.O.; Johari, M.A.M.; Ahmad, Z.A.; Maslehuddin, M. Effects of $\mathrm{H}_{2} \mathrm{O} / \mathrm{Na}_{2} \mathrm{O}$ molar ratio on the strength of alkaline activated ground blast furnace slag-ultrafine palm oil fuel ash based concrete. Mater. Des. 2014, 56, 158-164. [CrossRef]

13. Medri, V.; Ruffini, A. Alkali-bonded SiC based foams. J. Eur. Ceram. Soc. 2012, 32, 1907-1913. [CrossRef]

14. Rahman, A.S.; Shah, C.; Gupta, N. Simultaneous effects of rice husk silica and silicon carbide whiskers on the mechanical properties and morphology of sodium geopolymer. J. Compos. Mater. 2020, 0021998320928579. [CrossRef]

15. Medri, V.; Fabbri, S.; Ruffini, A.; Dedecek, J.; Vaccari, A. SiC-based refractory paints prepared with alkali aluminosilicate binders. J. Eur. Ceram. Soc. 2011, 31, 2155-2165. [CrossRef]

16. Bai, C.Y.; Zheng, J.; Rizzi, G.A.; Colombo, P. Low-temperature fabrication of SiC/geopolymer cellular composites. Compos. Part B 2018, 137, 23-30. [CrossRef]

17. Jia, D.C.; Li, Y.H.; He, P.G.; Fu, S.; Duan, X.M.; Sun, Z.L.; Cai, D.; Li, D.X.; Yang, Z.H.; Zhou, Y. In-situ formation of bulk and porous h-AlN/SiC-based ceramics from geopolymer technique. Ceram. Int. 2019, 45, 24727-24733. [CrossRef] 
18. Wan, Q.; Rao, F.; Song, S.X. Reexamining calcination of kaolinite for the synthesis of metakaolin geopolymers-roles of dehydroxylation and recrystallization. J. Non Cryst. Solids. 2017, 460, 74-80. [CrossRef]

19. Wei, B.; Zhang, Y.; Bao, S. Preparation of geopolymers from vanadium tailings by mechanical activation. Constr. Build. Mater. 2017, 145, 236-242. [CrossRef]

20. Hu, Y.; Liang, S.; Yang, J.K.; Chen, Y.; Ye, N.; Ke, Y.; Tao, S.Y.; Xiao, K.K.; Hu, J.P.; Hou, H.J.; et al. Role of Fe species in geopolymer synthesized from alkali-thermal pretreated Fe-rich Bayer red mud. Constr. Build. Mater. 2019, 200, 398-407. [CrossRef]

21. Lo, K.W.; Lin, K.L.; Cheng, T.W.; Shiu, H.S. Effect of alkali activation thin film transistor-liquid crystal display waste glass on the mechanical behavior of geopolymers. Constr. Build. Mater. 2018, 162, 724-731. [CrossRef]

22. Yaghoubi, M.; Arulrajah, A.; Disfani, M.M.; Horpibulsuk, S.; Darmawan, S.; Wang, J. Impact of field conditions on the strength development of a geopolymer stabilized marine clay. Appl. Clay Sci. 2019, 167, 33-42. [CrossRef]

23. Henon, J.; Alzina, A.; Absi, J.; Smith, D.S.; Rossignol, S. Porosity control of cold consolidated geomaterial foam: Temperature effect. Ceram. Int. 2012, 38, 77-84. [CrossRef]

24. Tiffo, E.; Mbah, J.B.B.; Belibi, P.D.B.; Djobo, J.N.Y.; Elimbi, A. Physical and mechanical properties of unheated and heated kaolin based-geopolymers with partial replacement of aluminium hydroxide. Mater. Chem. Phys. 2020, 239, 122103. [CrossRef]

25. Wan, Q.; Rao, F.; Song, S.X.; León-Patiño, C.A. Geothermal clay-based geopolymer binders: Synthesis and microstructural characterization. Appl. Clay Sci. 2017, 146, 223-229. [CrossRef]

26. Li, W.; Rao, F.; Song, S.X.; Ma, Q.Y. Deterioration in the microstructure of metakaolin-based geopolymers in marine environment. J. Mater. Res. Technol. 2019, 8, 2747-2752. [CrossRef]

27. Maekawa, H.; Maekawa, T.; Kawamura, K.; Yokokawa, T. The structural groups of alkali silicate glasses determined from ${ }^{29}$ Si Mas-NMR. J. Non Cryst. Solid. 1991, 127, 53-64. [CrossRef]

28. Wan, Q.; Rao, F.; Song, S.X.; García, R.E.; Estrella, R.M.; Patino, C.L.; Zhang, Y.M. Geopolymerization reaction, microstructure and simulation of metakaolin-based geopolymers at extended $\mathrm{Si} / \mathrm{Al}$ ratios. Cem. Concr. Compos. 2017, 79, 45-52. [CrossRef]

29. Lin, K.L.; Lo, K.W.; Cheng, T.W.; Lin, W.T.; Lin, Y.W. Influence of SiC Sludge on the Microstructure of Geopolymers. Materials 2020, 13, 2203. [CrossRef]

(C) 2020 by the authors. Licensee MDPI, Basel, Switzerland. This article is an open access article distributed under the terms and conditions of the Creative Commons Attribution (CC BY) license (http://creativecommons.org/licenses/by/4.0/). 